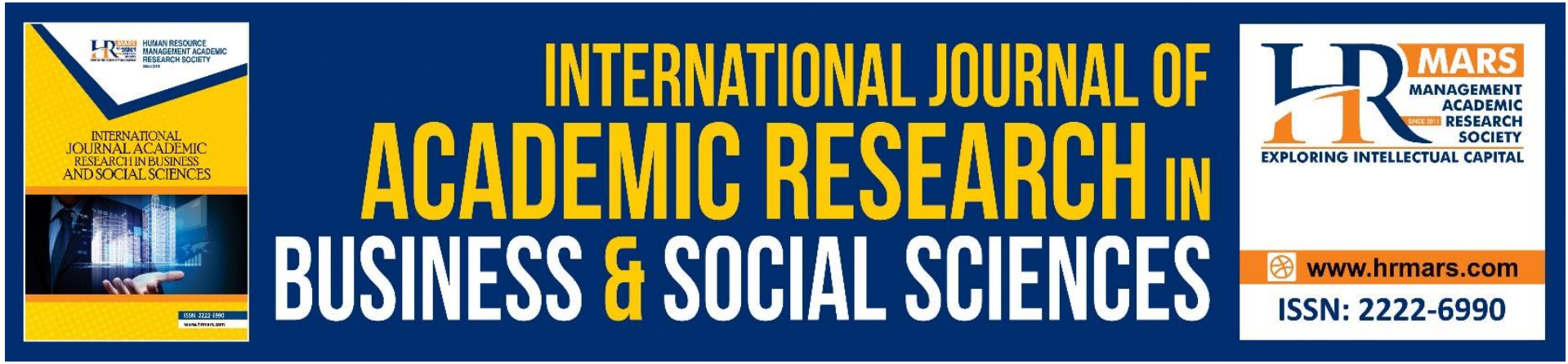

\title{
Development of VBA Program for Affordable Premium and Coverage for Lower Income Group in Malaysia
}

Noraini Manan, Nurhasniza Idham Abu Hasan, Nur Faezah Jamal, Nurhasnira Abu Hasan

To Link this Article: http://dx.doi.org/10.6007/IJARBSS/v11-i8/10745

DOI:10.6007/IJARBSS/v11-i8/10745

Received: 19 June 2021, Revised: 21 July 2021, Accepted: 11 August 2021

Published Online: 28 August 2021

In-Text Citation: (Manan et al., 2021)

To Cite this Article: Manan, N., Hasan, N. I. A., Jamal, N. F., \& Hasan, N. A. (2021). Development of VBA Program for Affordable Premium and Coverage for Lower Income Group in Malaysia. International Journal of Academic Research in Business and Social Sciences, 11(8), 1819-1831.

Copyright: @ 2021 The Author(s)

Published by Human Resource Management Academic Research Society (www.hrmars.com)

This article is published under the Creative Commons Attribution (CC BY 4.0) license. Anyone may reproduce, distribute, translate and create derivative works of this article (for both commercial and non-commercial purposes), subject to full attribution to the original publication and authors. The full terms of this license may be seen at: http://creativecommons.org/licences/by/4.0/legalcode

Vol. 11, No. 8, 2021, Pg. 1819 - 1831

Full Terms \& Conditions of access and use can be found at http://hrmars.com/index.php/pages/detail/publication-ethics 


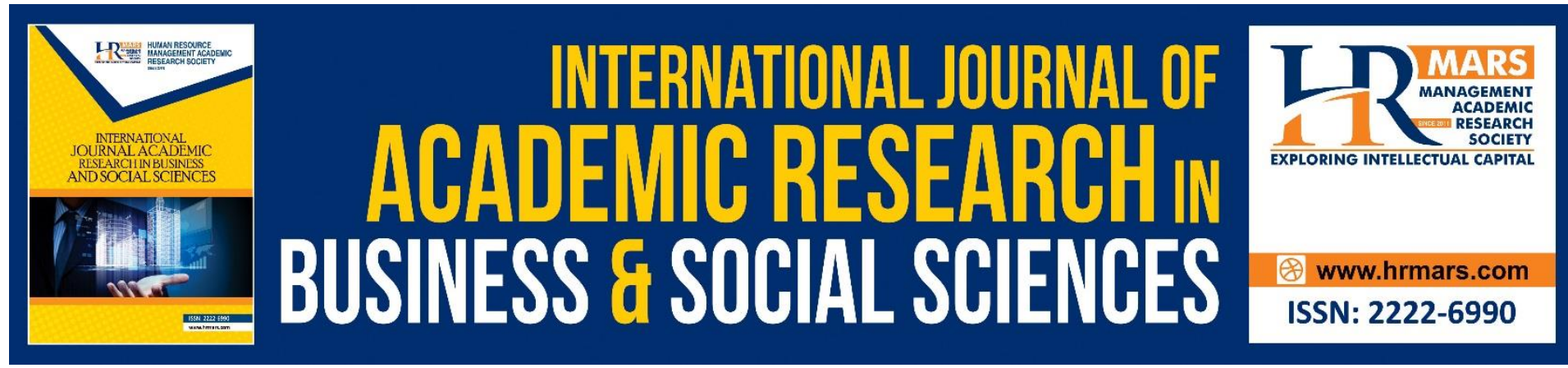

\title{
Development of VBA Program for Affordable Premium and Coverage for Lower Income Group in Malaysia
}

\author{
Noraini Manan ${ }^{1}$, Nurhasniza Idham Abu Hasan², Nur Faezah \\ Jamal $^{3}$, Nurhasnira Abu Hasan ${ }^{4}$ \\ ${ }^{1}$ Center for Actuarial Sciences Studies, Faculty of Computer \& Mathematical Sciences, \\ Universiti Teknologi MARA, 40450 Shah Alam, Malaysia, ${ }^{2.3}$ Department of Statistics, Faculty \\ of Computer \& Mathematical Sciences, Universiti Teknologi MARA, Perak Branch, Tapah \\ Campus,35400 Tapah Road, Perak, Malaysia, ${ }^{4} J a b a t a n$ Penyelidikan, Pembangunan \& \\ Inovasi, Tingkat 2 Bangunan RUKA, Pusat Perbuatan Universiti Malaya, 50603 Kuala Lumpur. \\ Email: noraini@tmsk.uitm.edu.my
}

\begin{abstract}
Most people should have insurance to protect themselves from damage and financial instability, especially for those in low income group B40. The objective of this study is to suggested affordable life insurance premium for the B40 group using equivalence principle method. The study's findings show that group can choose between two affordable life insurance policies is either policy 1 or policy 2. Next objective is to create a user-friendly calculator that displays life insurance and Takaful policies available in Malaysia based on the B40 monthly household income. Microsoft Excel and Visual Basic for Application (VBA) are used to accomplish this objective. It hoped that this userfriendly interface developed in this study may assist low-income earners in identifying a suitable range of premiums they may afford to pay, thereby increasing the likelihood of purchasing life insurance and Takaful.
\end{abstract}

Keywords: Premium, Equivalence Principle, Lower income group (B40), VBA

\section{Introduction}

Everyone should have coverage such as life insurance, Takaful, or any other product offered by insurance firms to ensure the protection of family and loved ones. Insurance coverage can be defined as the amount of risk or liability that an individual or organization covers through insurance services. Life insurance, on the other hand, is a financial product that protects consumers from financial loss. The majority of individuals buy insurance to protect themselves from damage and financial instability, especially unfavorable events occur (Manan et. al, 2019). Life insurance can be useful for financial protection and long-term planning. The primary goal of purchasing life insurance is to alleviate the financial stress and concern that people and their families would face in the case of the breadwinner's untimely death. 
Malaysians' ownership of life insurance is still not as favourable as expected, with just a small percentage of Malaysians owning life insurance or Takaful. Malaysia's combined market penetration rate for life insurance and Takaful was 55\% in 2015, much below the target rate of 75\% established by the Economic Transformation Programme for 2020 (Lim \& Tan, 2019). Meanwhile, in 2017, only 14.66 percent of Malaysians were protected by Takaful insurance for their families (Malaysian Takaful Association, 2017). Overall, 56 percent of Malaysians have insurance, leaving 44 percent of the population without life insurance or Takaful protection (Yakob et al., 2019). According to the statistics provided by Bank Negara Malaysia (2016) in the Financial Stability and Payment System Report 2016, only 4\% of 2.7 million low income households have life insurance and Takaful protection. According to the Malaysian Department of Statistics, there are three income groups in Malaysia with median incomes of RM13, 148, RM6, 275, and RM3, 000, referred to as the Top 20\% (T20), Middle 40\% (M40), and Bottom 40\% (B40), respectively (Yusoff et al., 2020). Although a lot of initiatives was introduces to attract people to the purchase of life insurance especially among B40 group. Nonetheless, only a small percentage of them are from the B40 group (Salleh et al., 2018).

Despite the advantages, life insurance consumption continues to be low, particularly among lower-income B40 groups. It is critical to increase the penetration rate of life insurance to alleviate the financial burden on family members when the breadwinner dies or becomes disabled. Previous research has discovered that many factors affect life insurance and Takaful consumption, including income, level of education, awareness, perception of insurance, household size, and regional location. President of the Life Insurance Association of Malaysia (LIAM), Loh Guat Lan, has remarked that life insurance should be acquired by everyone, especially those in the B40 group, and should not be seen as an additional financial burden (Krishnan, 2020). The B40's involvement in life insurance and Takaful is influenced by a number of factors. According to Olano (2019), the main determinants that affected insurance intention were largely focused on the family's income. The amount of money a family earns has an impact on their capacity to buy goods and services. This small family size is associated with a lower socioeconomic status (Puteh et al., 2019), which might impact their expenditures. There are numerous research attempt to investigate the demographic factor on purchasing insurance but no studies that investigate the available insurance schemes that can give financial protection to the B40 group during unexpected events. As a result, the goal of this study is to fill in the gaps in prior research in terms of scope and coverage. The objective of this paper is:

1. To propose affordable life insurance premium for the B40 group using equivalence principle method based on their monthly income.

2. To develop a user-friendly calculator that can show affordable life insurance premiums available in Malaysia among B40 group.

\section{Literature Review}

\section{Life insurance and takaful}

Life insurance is seen as a product that provides protection and savings. Life insurance is used by most Malaysian families for financial planning purposes, such as financial protection (Lajuni et al., 2020). The main feature of insurance is the transfer of risk, as it is created to act as a protection for individuals or companies against unexpected accidents (Gustina and Abdullah, 2012; Manan et al., 2019). A life insurance policy obligates the issuer's firm to pay a lump sum amount of money (depending on the paid insurance sum) to an insured person (beneficiary) 
or a party nominated by the insured person as a dependent beneficiary in the case of accidental death or attaining a specific age (Gustina and Abdullah, 2012). In addition, Life insurance covers long-term expenses such as mortgages, unpaid loans, and medical. There is an alternative form of insurance coverage for Muslim customers in today's insurance industry, which is called Takaful. Takaful is an Islamic insurance product in which each participant contributes money to a pool of funds that will help each participant in the event of a loss due to unexpected circumstances (Yakob et al., 2019). Takaful operators, like traditional composite insurance firms, provide both general Takaful and family Takaful policies. The contributions of family Takaful participants are divided into two distinct accounts. These accounts are the participants' investment accounts (PA), which is the savings and investment account, and the participants' special accounts (PSA), which is a donation fund based on the Tabarru' concept (Gustina and Abdullah, 2012).

\section{B40 Group Inclusivity in Obtaining Life Insurance}

According to the Malaysian Department of Statistics, there are three sorts of income categories with median incomes of RM13148, RM6275, and RM3000, designated as the Top 20\% (T20), Middle 40\% (M40), and Bottom 40\% (B40), correspondingly (Yusoff et al., 2020). Since most Malaysians are in the M40 and B40 groups, it is critical to cater to their needs in terms of protection in anticipation of unexpected losses where financial issues may arise. Medical care is one of the key concerns in developing nations like Malaysia. Unfortunately, healthcare in Malaysia is extremely expensive for people in the B40 age range. A survey of B40 groups was undertaken to see if they wanted to acquire insurance (Salleh et al., 2018). According to the findings, the majority of low-income group B40 are interested in obtaining insurance, but they can only afford to contribute approximately RM5-15 per month, and some of the respondent are unwilling to pay even RM5.

Medical care is one of the key concerns in developing nations like Malaysia. Unfortunately, healthcare in Malaysia is extremely expensive for people in the B40 age range. A survey of B40 groups was undertaken to see if they wanted to acquire insurance (Salleh et al., 2018). According to the findings, the majority of low-income group B40 are interested in obtaining insurance, but they can only afford to contribute approximately RM5-15 per month, and some of the respondent are unwilling to pay even RM5.

\section{Methodology \\ Data Description}

This analysis was based on data released by the Life Insurance Association of Malaysia (LIAM) in 2018 and 2019. The information contains the average benefit that a Malaysian should be able to obtain in the event of loss. Data about life insurance and Takaful schemes available can be found on the official websites of the relevant insurance companies. The schemes are targeted for lower income and not exceed RM100.

\section{Visual Basic for Application (VBA) software}

Microsoft Excel is widely used all over the world, particularly for management. Microsoft Excel, built by Microsoft, is very useful in managing available data efficiently, hence making it easier to analyse data statistically. According to GCF Global, some of the basic and simple functions to compute output are Sum, Average, Count, Max, and Min, which mean the sum 
of total, mean, number of cells counted, highest cell value, and lowest cell value of the selected dataset, respectively.

Visual Basic for Applications (VBA) is the internal programming language used by Microsoft Office (MS Office, Office) software such as Access where you will requires to create a set of instructions in form of programme to perform a specific action or series of actions (Kenton, 2020). VBA allows users to create user-defined functions (UDFs), access Windows application programming interfaces (APIs), and launch specific computer processes and calculations (Kenton, 2020). Through these features, users can create a two-way response from respondents and the user's automatic functions through coding. Kenton (2020) stated Macros through VBA can automate tasks, for example, produce customized graphs and reports, execute word and data-processing tasks and can transform a blank spreadsheet of Excel into sets of accounting entries with a single click.

\section{Software Development}

The main aim of this paper is to develop a user-friendly interface for $\mathrm{G} 40$ group to determine the most affordable premium income. The interface development procedures are illustrated in Fig.1. It involve three basic steps.

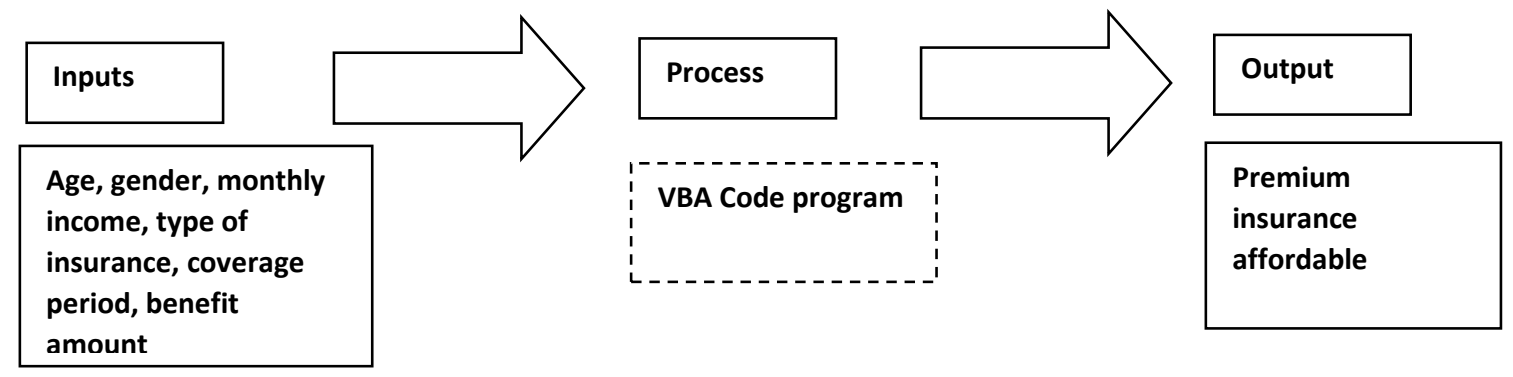

Figure 1. Proposed theoretical framework for premium insurance among B40 group

The first step is input where user were required such as age, gender, monthly income, type of insurance, coverage period and benefit amount (input). Then, all the input will be process using VBA code program that developed in this study (process). Then, the minimum premium that affordable based on user monthly income for B40 group will be generated from the system (output).

\section{Equivalent Principle calculator}

There are numerous methods for calculating premiums based on specific benefits and some for allocating expenses. One approach is by using the equivalence principle. The expected loss of an insurance policy to the insurance company is equal to zero under the equivalence principle (or priced) technique (Guat \& Ming, 2020). Thus, the policyholder will pay the expected present value of the future premium, E (PVFP) which will be the same as payment to an insurance company, which is the sum of the expected present value of the future benefit E (PVFB). 


$$
E(P V F P)=E(P V F B)
$$

The expressions for the E(PVFB) and E(PVFP) are as follows :

$$
\begin{aligned}
& \mathrm{E}(\mathrm{PVFB})=S \times \sum_{k=0}^{n-1}\left(\frac{1}{1+r}\right)^{k+1} \times k \mid q_{x} \\
& \mathrm{E}(\mathrm{PVFP})=P \times \sum_{k=0}^{n-1}\left(\frac{1}{1+r}\right)^{k+1} \times k p_{x}
\end{aligned}
$$

where $k \mid q_{x}=$ Probability of mortality

$$
\begin{aligned}
k p_{x} & =\text { Probability of surviving } \\
P & =\text { Annually premium payable at the beginning of each year } \\
S & =\text { Benefit payable at the end of the year } \\
r & =\text { Interest rate per year }
\end{aligned}
$$

There are important factors that must be considered to produce a reasonable premium, which are (1) financial situation and (2) the wages of lower-income residents. Many premiums make low-income families reluctant to have insurance (Guat \& Ming, 2020) because they are burdened by the cost. As our first objective to produce affordable premium insurance, some assumptions were adopted for the calculation such as follows.

(1) This life insurance is a 10-year term insurance with benefits payable at the end of the year of death and the premium is paid annually at the beginning of each year.

(2) The mortality rate is being considered, and the rate was calculated using the Standard Ultimate Life Table.

(3) Two coverage values were proposed if the policyholder wants higher protection amount: RM100, 000 (Policy 1) and RM550, 000 (Policy 2).

(4) The annual interest rate is assumed to be $3.5 \%$.

Research done by Guat and Ming (2020) proposed the concept of "income based subsidy" where the government is responsible for covering a certain percentage of amount to ease the burden of policyholders in paying higher monthly commitments. In this study, we are going to use Guat approach to determine how much of the premium for B40 group can be affordable. In the meanwhile, the government will cover the remaining portion of the premium.

\section{Result and Discussion}

\section{New Life Insurance Product}

Discrete term life insurance is the type of life insurance used in the equivalence principle method. Let assume $x$ as age in years, discrete term life insurance pays a benefit of a certain amount at the end of the year of death only if death occurs within $n$ years of the issue. There are two products has been proposed in this study that may suit with B40 groups which is policy 1 and policy 2 . The three assumptions were applied for any of policy as follows:

- Sum assured of RM100, 000 for Policy 1 and RM550, 000 for Policy 2.

- The duration of coverage, $n$ is 10 years.

- The interest rate is $3.5 \%$. 
Table 1. Net Annual Premium for Policy 1 and Policy 2

\begin{tabular}{|l|l|l|l|}
\hline Policy 1 RM100,000 & \multicolumn{3}{l|}{ Policy 2 RM550,000 } \\
\hline Category of Age & Premium (RM) & Category of Age & Premium (RM) \\
\hline 20 & 15.73 & 20 & 86.51 \\
\hline 30 & 22.33 & 30 & 122.82 \\
\hline 40 & 43.57 & 40 & 239.63 \\
\hline 50 & 186.28 & 50 & 614.72 \\
\hline
\end{tabular}

Table 1 shows the suggested annual premium for B40 family after B40 households receive $40 / 50 \%$ subsidies. The corresponding premium is calculated annually to give insight into how much is consumed by insurance. It can be seen that the annual premium for Policy 1 is significantly lower than Policy 2. It is predictable since the amount of benefit in Policy 2 is more than five times the benefit in Policy 1 . In the early age of entry such as 20 years, resulted in the lowest premium for both policies, which become an advantageous for young adults to have the insurance. For example, families that earn less than RM2, 500 per month (B40) just need to pay RM43.57 a year for Policy 1 with the government subsidising 40 percent of the cost. If they want a higher level of insurance coverage, they can opt for Policy 2 , which costs RM 239.63 per year.

The VBA Programming code to calculate premiums using the equivalence principle as follows.

Private Sub CommandButton1_Click()

Dim Age As Integer Dim Term As Integer Dim benefit As Single Dim interest As Single Dim EPVB As Single Dim klqx As Single Dim TermP As Single Dim EPVP As Single Dim tpx As Single Dim Premium As Single

Age $=\operatorname{Cells}(3,8)$ Term $=\operatorname{Cells}(4,8)$ benefit $=\operatorname{Cells}(5,8)$ interest $=\operatorname{Cells}(6,8)$ If Age $<20$ Or Age $>100$ Then

MsgBox ("Age must between 20 to 100") End

Elself Term + Age $>100$ Then

MsgBox ("Final age must not be more than 100") End

End If

'to calculate EPV(Benefit)

For $\mathrm{k}=0$ To Term -1

Ix=WorksheetFunction.VLookup(Age,Sheet2.Range("B6:D 87"),2,0)

Ixk=WorksheetFunction.VLookup(Age+k, Sheet2.Range("B6:D87"),2,0)

Ixk1=WorksheetFunction.VLookup(Age+k+1,Sheet2.Range ("B6:D87"),2,0)

$k \mid q x=(|x k-| x k 1) / I x E P V B=E P V B+(1+\text { interest })^{\wedge}-(k+1)^{*} k l q x$

Next $k$

Cells $(9,8)=$ EPVB

'to calculate EPV(Premium) TermP $=\operatorname{Cells}(4,8)$

For $\mathrm{t}=0$ To TermP -1 
Ix=WorksheetFunction.VLookup(Age,Sheet2.Range("B6:D 87"),2,0)

Ixt=WorksheetFunction.VLookup(Age+t,Sheet2.Range("B 6:D87"),2,0)

tpx $=\mid x t / l x$ EPVP $=E P V P+(1+\text { interest })^{\wedge}-t^{*}$ tpx

Next t Cells $(10,8)=$ EPVP

Premium $=$ benefit* $($ EPVB/EPVP $) * 0.6$ Cells $(11,8)=$ Premium

End Sub

\section{Result}

After input a certain value, then the output will display as in Table 2.

Table 2. Output Display

\begin{tabular}{|l|l|}
\hline Type of insurance & Term life insurance \\
\hline Age & 50 \\
\hline Term & 10 \\
\hline Benefit & 550000 \\
\hline Interest & $3.5 \%$ \\
\hline EPV Benefit & 0.01592656 \\
\hline EPV Premium & 8.549775124 \\
\hline Premium & 614.7255249 \\
\hline
\end{tabular}

\section{Build-in Calculator using Visual Basic for Applications (VBA)}

\section{Criteria for Selecting Policy}

Most insurance companies provide similar types of insurance and underwriting. In conjunction with the Perlindungan Tenang campaign, several well-known companies have joined to provide affordable premiums and convenient underwriting policies. The table of insurance schemes available in Malaysia are listed in Table 3. The criteria for selecting the premium for an insurance policy and contribution for Takaful cannot exceed RM50.

Table 3. Table of Insurance Products in Malaysia

\begin{tabular}{|l|l|l|l|l|l|}
\hline $\begin{array}{l}\text { Type of } \\
\text { Insurance }\end{array}$ & Company & Age & $\begin{array}{l}\text { Coverage } \\
\text { period }\end{array}$ & $\begin{array}{l}\text { Minimum } \\
\text { benefit (RM) }\end{array}$ & $\begin{array}{l}\text { Premium } \\
\text { (monthly) }\end{array}$ \\
\hline Conventional & AlA Starter Plan & $16-55$ & 1 & 10000 & 2.87 \\
\hline Conventional & Etiqa Ezy-Life Secure & $16-59$ & 5 & 50000 & 12.40 \\
\hline Conventional & Allianz Kasih Hayat Plan 1 & $18-40$ & 1 & 10000 & 3.17 \\
\hline Conventional & Allianz Kasih Hayat Plan 1 & $41-50$ & 1 & 10000 & 6.33 \\
\hline Conventional & Allianz Kasih Hayat Plan 1 & $51-60$ & 1 & 10000 & 14.58 \\
\hline Conventional & Allianz Kasih Hayat Plan 2 & $18-40$ & 1 & 20000 & 4.83 \\
\hline Conventional & Allianz Kasih Hayat Plan 2 & $41-50$ & 1 & 20000 & 11 \\
\hline Conventional & Allianz Kasih Hayat Plan 2 & $51-60$ & 1 & 20000 & 27.67 \\
\hline
\end{tabular}


INTERNATIONAL JOURNAL OF ACADEMIC RESEARCH IN BUSINESS AND SOCIAL SCIENCES Vol. 11, No. 8, 2021, E-ISSN: 2222-6990 @ 2021 HRMARS

\begin{tabular}{|c|c|c|c|c|c|}
\hline Conventional & $\begin{array}{l}\text { Hong Leong Assurance } \\
\text { Active Lifestyle Protector } \\
\text { Premier }\end{array}$ & $16-50$ & 5 & 10000 & 75 \\
\hline Conventional & $\begin{array}{lll}\text { Hong } & \text { Leong } & \text { Assurance } \\
\text { Active } & \text { Lifestyle } & \text { Protector } \\
\text { Deluxe } & & \\
\end{array}$ & $16-50$ & 5 & 5000 & 30 \\
\hline Conventional & Manulife Manu Protect & $17-60$ & 5 & 50000 & 4.65 \\
\hline Conventional & Zurich TermLife & $16-65$ & 5 & 50000 & Vary \\
\hline Conventional & $\begin{array}{l}\text { Hong Leong Assurance } \\
\text { Term Cover } 10\end{array}$ & $16-65$ & 10 years & 500000 & 9 \\
\hline Conventional & TokioMarine StarterPack & $18-55$ & $\begin{array}{l}\max \\
\text { coverage: } \\
60 \text { years } \\
\end{array}$ & 25000 & 15 \\
\hline Conventional & $\begin{array}{l}\text { MCIS Life Merchantrade } \\
\text { Insure Life }\end{array}$ & $18-60$ & $\begin{array}{l}\max : 65 \\
\text { years }\end{array}$ & 4000 & 1 to 5 \\
\hline Conventional & $\begin{array}{l}\text { Great Eastern Easy Care } \\
\text { Plus }\end{array}$ & $18-40$ & 1 & 40000 & 10 \\
\hline Conventional & $\begin{array}{l}\text { Great Eastern Easy Care } \\
\text { Plus }\end{array}$ & $41-59$ & 1 & 15000 & 10 \\
\hline Conventional & $\begin{array}{l}\text { MCIS Life Merchantrade } \\
\text { Insure Life }\end{array}$ & $18-60$ & $\begin{array}{l}\max : 65 \\
\text { years }\end{array}$ & 4000 & 1 to 5 \\
\hline Conventional & Sun Life Malaysia Go Life 5 & $\begin{array}{l}\min : \\
18\end{array}$ & $\begin{array}{l}\max : \text { age } \\
50\end{array}$ & 18000 & 5 \\
\hline Conventional & Sun Life Malaysia Go Life 10 & $\begin{array}{l}\min : \\
18\end{array}$ & $\begin{array}{l}\max : \text { age } \\
50\end{array}$ & 38000 & 10 \\
\hline Takaful & FWD Takaful FWD Kasih & $19-54$ & $\begin{array}{l}\max : \text { age } \\
54\end{array}$ & 10000 & 2.03 \\
\hline Takaful & Etiqa Takaful i-Secure & $21-45$ & $\begin{array}{l}\min : \quad 5 \\
\text { years, } \\
\max \text { age: } \\
75\end{array}$ & 100000 & 12.4 \\
\hline Takaful & $\begin{array}{l}\text { Etiqa Takaful } \\
\text { DoubleSecure }\end{array}$ & $17-54$ & $10,15,20$ & 50000 & 25.73 \\
\hline Takaful & Takaful Privilege PA & $18-60$ & 1 & 400000 & 43.57 \\
\hline Takaful & BIMA Life Takaful Plan & $18-50$ & $\begin{array}{l}\max \\
\text { coverage: } \\
50 \text { years }\end{array}$ & 20000 & 5 \\
\hline
\end{tabular}

\section{Function and Statement Involved in VBA}

A command button box with caption of "Click Here for Calculator" is placed in Microsoft Excel first sheet was use to launch this build calculator. These statements are very useful to produce looping and make sure the output produced is in line with the user's input. The tools involved with their corresponding functions are listed in Table 4. 
Table 4. Code in VBA

\begin{tabular}{|l|l|l|}
\hline Type & Name & Function \\
\hline \multirow{3}{*}{ TextBox } & txtAge & Input for age \\
\hline LabelBox & txtIncome & Input for monthly income \\
\hline & txtPeriod & Input for the coverage period \\
\hline & IblAge & To label age \\
\hline & IblGender & To label gender \\
\hline Ibllncome & To label monthly income \\
\hline IblType & To label the type of insurance \\
\hline ComboBox & IblPeriod & To label coverage period \\
\hline SpinBumAssured & To label sum assured \\
\hline Listbox & IblShowPremium & To display a message of suggested premium \\
\hline CombType & To list Conventional and Takaful \\
\hline SpinButton & To increase and decrease the number in LabelBox5 \\
\hline listSumAssured & To list the available sum assured \\
\hline listInsurance & To list available insurance schemes based on user input \\
\hline & cmdCalculate & Execute coding to calculate the age with its \\
& corresponding scheme \\
\hline & cmdReset & Execute coding to reset the input box and listbox. \\
\hline cmdExit & Execute coding to exit userform. \\
\hline
\end{tabular}

\section{User Interface}

VBA coding and user form are used to create a built-in calculator. This calculator's function is to match the user's desired category with the corresponding available insurance scheme in Malaysia. The function of this build calculator is to display the suggested monthly premium based on monthly income of B40 group. In this interface, several inputs were required such as age, gender, monthly income, type of insurance, coverage period and benefit amount. Users are requires to select their category to find a suitable policy affordable according to their input value. There are two types of insurance in Malaysia such as: Conventional and Takaful. The user interface template is as in Figure 2.

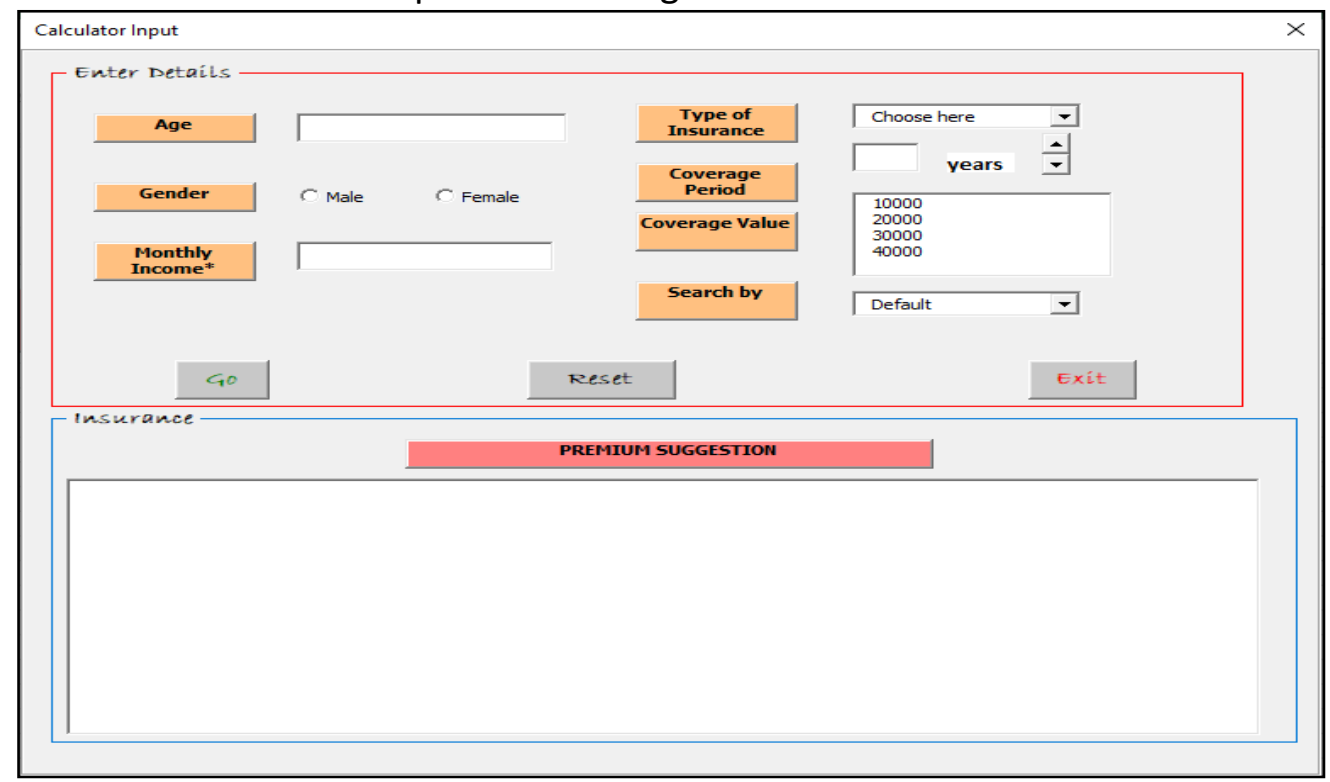

Figure 2. Blank Template of User Interface 
This proposed calculator helps to calculate $6 \%$ of user's monthly income and displays the affordable premium at the suggested box. When the user types in all the inputs, the list box will display the insurance scheme depending on the age of the user.

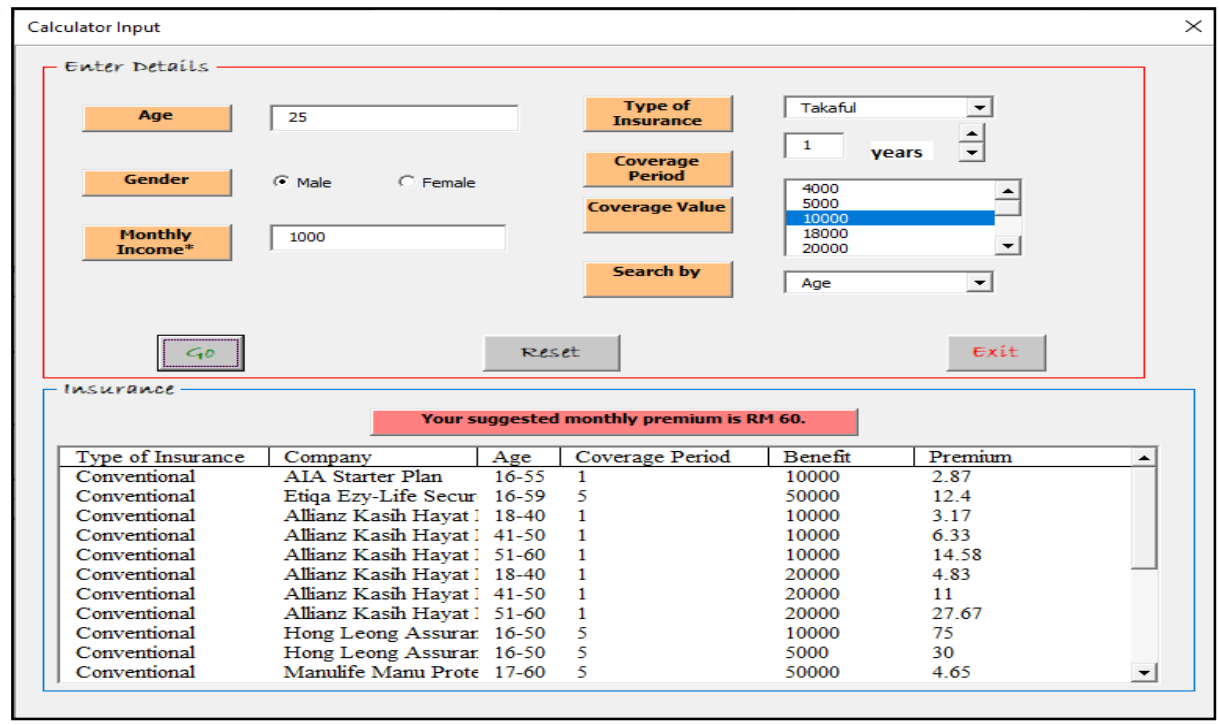

Figure 3. Example of Output Produced

\section{Conclusion}

Takaful and life insurance are both financial instruments designed to provide financial security and long-term planning. Due to the current extreme rise in the cost of living, it is more important than ever for individuals to be adequately insured, particularly those in the lower-income B40 group. However, the market penetration rate for life insurance and Takaful is extremely low, with only a small percentage coming from the B40 group. The Equivalence Principle was used to calculate affordable premiums based on specific benefits and expenses to achieve the first goal. The study's findings show that the B40 group can choose between two affordable life insurance policies: policy 1 and policy 2 .

These policies are discrete term life insurance with a coverage period of 10 years, an interest rate of 3.5\%, and a sum assured of RM100, 000 for Policy 1 and RM550, 000 for Policy 2. According to the Malaysian Takaful Association (2017), the ideal amount of benefit from death for a family of five to survive in five years is RM 550,000. The user should select Policy 2. However, the amount of premium might be too expensive or costly for some members of B40 group, thus, Policy 1 was designed. Policy 1 was design based on lower sum assured and more affordable than Policy 2. The amount of premium is as low as RM 15.73 per month, which is a reasonable price for the lower- income group B40.

Next main objective is to create a user-friendly calculator that displays life insurance and Takaful policies available in Malaysia based on the B40 monthly household income. Microsoft Excel and Visual Basic for Application (VBA) are used to accomplish this objective. Users need to input their category such as age, gender, and monthly income, type of insurance, coverage period, and benefit amount that determine their information in order to find a suitable policy based on their input value. The proposed calculator only includes conventional and Takaful schemes with low monthly commitments since it was designed for the B40 insurance scheme. It hope that government should consider an income- based subsidy to subsidise 
lower and moderate-income earners (Guat \& Ming, 2020). The government should also establish a specific fund for insurers charged with producing B40-friendly life insurance and Takaful products. As a result of the government injection, it is possible to lower the total monthly payment for premium insurance and Takaful contributions.

\section{Acknowledgement}

We would like to acknowledge the researchers and subjects involved in this study. Students of degree in Bsc. Actuarial Science from University Technology MARA, with guidance from Noraini Manan started the study case and the study then extended by the rest of the named researchers. In General insurance and Takaful there is a need to produce more applications like this for future clients to investigate and understand the insurance products. This research is in mind to help the insurance and Takaful industry to produce efficient services to their B40 future clients.

\section{References}

Bakri, S. M., Ramli, N. R. @, \& Sulaiman, N. A. (2018). Insurance Coverage amongst Low Income Households (B40) in Perak. International Journal of Academic Research in Business and Social Sciences, 8(11), 1733-1746.

Bank Negara Malaysia. (2016). The Financial Stability and Payment Systems Report 2016. https://www.bnm.gov.my/documents/20124/856371/fs2016_book.pdf.

Guat, C. L., \& Ming, L. K. (2020). Introduction of flood insurance and flood hazard map in Kota Bahru, Malaysia. In AIP Conference Proceedings. 2266(1), 03001.

Gustina, \& Abdullah, N. I. (2012). Analysis of demand for family takaful and life insurance: a comparative study in Malaysia. Journal of Islamic Economics, Banking and Finance, 8(4), 67-86.

Kenton, W. (2020). Visual Basic for Applications (VBA). Investopedia. https://www.investopedia.com/terms/v/visual-basic-for-applications-vba.asp

Krishnan, D. B. (2020). LIAM urges Malaysians to get life insurance coverage. New Straits Times Online. https://www.nst.com.my/news/nation/2020/09/623238/liam-urgesmalaysians-get-life-insurance-coverage

Lajuni, N., Lai, F. H., Sondoh Jr, S., \& Mohidin, R. (2020). Consumer knowledge effect on intention to purchase life insurance. Labuan e-Journal of Muamalat and Society (LMS), 69-79.

Life Insurance Association of Malaysia. (2019). https://www.liam.org.my/about/?c=1\&ct=1

Lim, C. C., \& Tan, S. S. (2019). Demographic profiling of life insurance ownership in the northern regions of Malaysia. International Journal of Business and Society, 20(3), 10221035.

Malaysian Takaful Association. (2017). 2017 Annual Report. https://www.malaysiantakaful.com.my/sites/default/files/2020-03/AR-2017.pdf

Manan, N., Hasan, N. I. A., Hasan, N. A., Jamal, N. F., \& Rahidin, N. D. A. B. M. (2019). Impact De-Tarrification in Modeling Motor Insurance Premium in Malaysia. International Journal of Recent Technology and Engineering, 8(3), 7394-7400.

Olano, G. (2020). Malaysian life market grows 14\% in 2019. Insurance Business Asia. https://www.insurancebusinessmag.com/asia/news/breaking-news/malaysian-lifemarket-grows-14-in-2019-217249.aspx 
Puteh, S. E. W., Siwar, C., Zaidi, M. A. S., \& Kadir, H. A. (2019). Health related quality of life (HRQOL) among low socioeconomic population in Malaysia. BMC public health, 19(4), 1-8.

Salleh, F., Mustafa, N., Daud, W. N. W., Yazid, A. S., Ghazali, P. L., Burhan, N. A. S., \& Hosnih, M. N. (2018). Micro health takaful framework for poor communities in Malaysia. International Journal of Academic Research in Business and Social Sciences, 8(11), 1294-1302.

Yakob, R., Hafizuddin-Syah, B. A. M., \& Hisham, N. H. B. (2019). Demographic analysis towards the understanding of Education Takaful (Islamic Insurance) Plan. Geografia-Malaysian Journal of Society and Space, 15(4).

Yusoff, N. D., Roslan, A., \& Arifin, A. M. (2020). Purchasing decision of microtakaful among B40 income group. International Journal of Business and Economy, 2(1), 55-67. 